\title{
AMENDMENTS
}

\section{Author Correction: The root meristem is shaped by brassinosteroid control of cell geometry}

\author{
Y. Fridman, S. Strauss (D), G. Horev (D), M. Ackerman-Lavert, A. Reiner-Benaim, B. Lane (D), R. S. Smith (D) and
} S. Savaldi-Goldstein (D)

Correction to: Nature Plants https://doi.org/10.1038/s41477-021-01014-9, published online 15 November 2021.

In the version of this article initially published, there were errors in the Fig. 1 color key. In the key, "Cortex" should have been by the blue bar, rather than yellow, and "Endodermis" by the yellow bar, rather than blue. The errors have been corrected in the html and PDF versions of the article.

Open Access This article is licensed under a Creative Commons Attribution 4.0 International License, which permits use, sharing, adaptation, distribution and
reproduction in any medium or format, as long as you give appropriate credit to the original author(s) and the source, provide a link to the Creative Commons
license, and indicate if changes were made. The images or other third party material in this article are included in the article's Creative Commons license,
unless indicated otherwise in a credit line to the material. If material is not included in the article's Creative Commons license and your intended use is not permitted by statutory
regulation or exceeds the permitted use, you will need to obtain permission directly from the copyright holder. To view a copy of this license, visit http://creativecommons.org/
licenses/by/4.0/.

Published online: 11 January 2022

https://doi.org/10.1038/s41477-022-01095-0

(C) The Author(s) 2022 